\title{
INFECTION CONTROL AND HYGIENE PRACTICES IN SKIN PENETRATION BUSINESSES
}

Ron Bouwman*, Santo Cannata, Mark Bek and Michael Fett

all formerly Central and Southern Sydney Area Public Health Unit

*current address Western Sector Public Health Unit

$\mathrm{T}$ he infection control practices of services that involve skin penetration were surveyed before and after the introduction of skin penetration guidelines. There were inadeqacies in infection control in some sectors of the industry, and this did not change significantly after the introduction of the guidelines.

Personal services involving skin penetration for cosmetic and health-related purposes are widely used by the public. These services are carried out by tattooists, acupuncturists, ear piercers, beauty therapists, barbers and hairdressers. Public and private health professionals may carry out these procedures but they are not considered in this paper.

The risk of transmission of infectious diseases through percutaneous exposure is widely recognised. ${ }^{1}$ In particular, reports of the transmission of hepatitis $\mathrm{B}$ virus (HBV) and hepatitis $\mathrm{C}$ virus ( $\mathrm{HCV}$ ) infection through tattooing have identified these viruses as risks to skin penetration workers and their clients..$^{2-4}$ Among Australian Navy personnel, the number of tattoos is positively correlated with the prevalence of serological markers of HBV infection. ${ }^{5} \mathrm{HBV}$ transmission has also occurred through acupuncture. ${ }^{6}$ Because routes of transmission of HBV and HIV are similar, HIV infection is also a potential occupational hazard for skin penetration workers and their clients. ${ }^{7}$

Pseudomonas aeruginosa, Staphylococcus aureus and Streptococcus spp. have been cultured from infections contracted after ear piercing and thus also represent hazards from skin penetration procedures. ${ }^{8,9}$

In 1985, the Public Health Act 1902 (NSW) was amended to include the Skin Penetration Regulation 1985 , which was aimed at introducing infection control measures into the skin penetration industry. In April 1991 the Public Health Act 1902 was repealed. In March 1991 the NSW Department of Health published infection control advice in the skin penetration guidelines, and in November 1991 gazetted regulations under the Public Health Act 1991, which rationalised the requirements. ${ }^{10}$ Practitioners needed to comply with the provisions of the regulation, and the guidelines provided a method to achieve this compliance.

To assess the status of the industry's infection control practices and monitor the effect of the guidelines, we studied the infection control practices of the skin penetration industry.

\section{METHODS}

A before-and-after survey design was used, with the first survey during the months before the distribution of the skin penetration guidelines and the second three years after. The first survey, in November and December 1991, focused on instrument sterilisation procedures and the handling and disposal practices for sharps and contaminated materials. The second survey was carried out from February to October 1994 on the previously surveyed premises, where the same aspects were reassessed.

Premises for survey were randomly selected from lists of skin penetration premises registered with the 14 local councils in the Central Sydney Area and the former Southern Sydney Area. About half the premises on the registers were selected for inspection and interview of the manager with a structured questionnaire. The surveyed skin penetration procedures included acupuncture, ear piercing, electrolysis (hair removal using an electrified needle), depilation (hair removal using wax), pedicure (the removal of corns and treatment of other foot conditions with cutting and abrasive tools), lancing (the removal of blackheads, ingrown hairs etc. with a lancet) and pigment implantation (injection of permanent inks to colour the skin, usually on the face).

Traditional tattooists were excluded from the survey as there was only one practitioner in the area and therefore no representative indication of workers' practices.

Procedures were assessed in relation to those approved in the skin penetration guidelines: the disposal of singleuse skin penetration instruments and the autoclaving of reusable instruments.

Each premises was also assessed on the adequacy of hygiene facilities such as hand-wash basins and soap, the use of disposable or non-disposable hand towels or automatic hand dryers and the use of hospital-grade disinfectant for the cleaning of the premises. Although hospital-grade disinfectant was not specified in the guidelines, its use was in the past required under the Local Government Act legislation for the cleaning of premises, and therefore its presence was used as a hygiene indicator. Verbal advice was provided to managers on any inadequacies in sterilisation of equipment, the handling and disposal of waste, and the repair, cleanliness and hygiene of premises identified at the time of inspection.

Data for the baseline survey were entered into CRS database software and analysed with SAS software: ${ }^{11,12}$ for the second survey data were entered into and analysed with Epi-Info database software. ${ }^{13}$

\section{RESULTS}

Eighty-six (51 per cent) of the 170 skin penetration premises registered with the local councils were approached for the baseline survey. The response rate was 100 per cent. Sixty-three of the initially surveyed premises were resurveyed. The number was reduced because operators had moved and could not be located or had ceased offering skin penetration services. In the final survey, more operators were found to offer lancing and 
pedicure procedures than in the baseline survey, which may reflect normal trade variations. The most common combinations of services offered at premises in the final survey are shown in Table 2. Over half of the premises conducted either solely ear piercing or solely acupuncture.

The disposal and reuse of instruments and the use of approved and non-approved sterilisation procedures are shown in Table 3. The predominant infection control practice in all procedures except pedicure was the use of disposable single-use skin-penetration instruments. The only ear-piercing procedure used was insertion of presterilised studs into the ear with a gun, which complied with the guidelines. No evidence was found of the re-use of depilation wax for more than one client.

The repeat survey revealed a slight but not significant increase in the use of disposable instruments for acupuncture and pigment implantation (which was already common) and for electrolysis, lancing and pedicure. Eight different methods were used to clean reusable instruments. Only one method, autoclaving, is approved as sterilisation in the skin penetration guidelines. In the repeat survey, only one of the 37 businesses reusing instruments used an autoclave. Among those reusing skin penetration instruments, there was a significant decrease in the use of approved sterilisation procedures from 17 per cent $(5 / 29)$ to 3 per cent $(1 / 37)(P<0.05)$. Overall, 22 per cent of procedures in the final survey continued to be performed with reusable instruments not sterilised in an approved manner.

\begin{tabular}{|c|c|c|c|c|}
\hline \multicolumn{5}{|c|}{$\begin{array}{l}\text { MOST COMMON PROCEDURES AND } \\
\text { COMBINATIONS OF PROCEDURES IN SURVEYED } \\
\text { SKIN PENETRATION BUSINESSES }\end{array}$} \\
\hline & \multicolumn{2}{|c|}{1991} & \multicolumn{2}{|c|}{1994} \\
\hline Procedures & $n$ & $\%$ & $n$ & $\%$ \\
\hline Ear piercing only & 27 & 31 & 18 & 28 \\
\hline Acupuncture only & 22 & 26 & 15 & $24^{\mathrm{a}}$ \\
\hline Ear piercing, electrolysis & 5 & 6 & 0 & 0 \\
\hline $\begin{array}{l}\text { Depilation, ear piercing, } \\
\text { electrolysis, lancing and } \\
\text { pedicure }\end{array}$ & 0 & 0 & 10 & 16 \\
\hline $\begin{array}{l}\text { Depilation, ear piercing, } \\
\text { electrolysis, lancing, pedicure } \\
\text { and pigment implantation }\end{array}$ & 0 & 0 & 5 & 8 \\
\hline Other combinations $\mathrm{s}^{\mathrm{a}}$ & 32 & 37 & 15 & 24 \\
\hline Total & 86 & 100 & 63 & 100 \\
\hline
\end{tabular}

Note:

(a) No other combination of procedures was undertaken by more than 3 businesses.

The use of safe and appropriate sharps and contaminated waste storage receptacles and licensed removal contractors had increased upon resurvey (Table 4).

Deficiencies in hygiene practices were evident in the absence of hospital-grade disinfectant in almost two-thirds of premises and the absence of hand-wash basins, soap

TABLE 3

\section{SKIN PENETRATION BUSINESSES COMPLYING WITH INFECTION-CONTROL GUIDELINES IN 1991 AND 1994 SURVEYS, BY TYPE OF PROCEDURE}

\begin{tabular}{|c|c|c|c|c|c|c|c|c|c|c|c|c|c|c|}
\hline \multirow{3}{*}{$\begin{array}{l}\text { Business } \\
\text { procedure }^{a}\end{array}$} & \multicolumn{4}{|c|}{$\begin{array}{l}\text { Compliance: use of } \\
\text { disposable instruments } \\
\text { only }\end{array}$} & \multicolumn{4}{|c|}{$\begin{array}{l}\text { Compliance: reuse of } \\
\text { some or all instruments } \\
\text { and approved } \\
\text { sterilisation }\end{array}$} & \multicolumn{4}{|c|}{$\begin{array}{l}\text { Noncompliance: reuse } \\
\text { of some or all } \\
\text { instruments and non- } \\
\text { approved sterilisation }\end{array}$} & \multicolumn{2}{|c|}{$\begin{array}{c}\text { Total } \\
\text { procedures }\end{array}$} \\
\hline & \multicolumn{2}{|c|}{1991} & \multicolumn{2}{|c|}{1994} & \multicolumn{2}{|c|}{1991} & \multicolumn{2}{|c|}{1994} & \multicolumn{2}{|c|}{1991} & \multicolumn{2}{|c|}{1994} & \multirow{2}{*}{$\begin{array}{c}1991 \\
n\end{array}$} & \multirow{2}{*}{$\begin{array}{c}1994 \\
n\end{array}$} \\
\hline & $n$ & $\%$ & $n$ & $\%$ & $n$ & $\%$ & $n$ & $\%$ & $n$ & $\%$ & $n$ & $\%$ & & \\
\hline Acupuncture & 19 & 86 & 13 & 87 & 1 & 4 & 0 & 0 & 2 & 9 & 2 & 13 & 22 & 15 \\
\hline Depilation & 23 & 100 & 29 & 100 & 0 & 0 & 0 & 0 & 0 & 0 & 0 & 0 & 23 & 29 \\
\hline Ear piercing & 55 & 100 & 39 & 100 & 0 & 0 & 0 & 0 & 0 & 0 & 0 & 0 & 55 & 39 \\
\hline Electrolysis $^{b}$ & 18 & 64 & 17 & 71 & 1 & 4 & 0 & 0 & 9 & 31 & 7 & 29 & 28 & 24 \\
\hline Lancing & 12 & 63 & 21 & 84 & 2 & 10 & 0 & 0 & 5 & 26 & 4 & 16 & 19 & 25 \\
\hline Pedicure ${ }^{c}$ & 0 & 0 & 0 & 0 & 1 & 14 & 1 & 4 & 6 & 86 & 23 & 96 & 7 & 24 \\
\hline Pigment implant & 7 & 78 & 8 & 100 & 0 & 0 & 0 & 0 & 2 & 22 & 0 & 0 & 9 & 8 \\
\hline All procedures & 134 & 82 & 127 & 77 & 5 & 3 & 1 & $<1$ & 24 & 15 & 36 & 22 & 163 & 164 \\
\hline \multicolumn{15}{|c|}{$\begin{array}{l}\text { Notes: } \\
\text { (a) Some premises undertook more than one procedure. These may appear in multiple rows. } \\
\text { (b) At some premises, instruments were reused for some clients and disposed of for others. } \\
\text { (c) Multiple instruments were used in pedicure treatments. Some were disposed of after use. }\end{array}$} \\
\hline
\end{tabular}


and towels (Table 5). The recommended use of disposable paper towels or automatic hand dryers for hygiene purposes was largely ignored, as only 10 per cent of premises used disposable paper hand towels and only 5 per cent used automatic hand dryers.

Information was also collated on throughput of clients at the surveyed premises. We estimate that at the time of the final survey, about 47 lancing procedures and 107 pedicure procedures were carried out per week with inadequately sterilised instruments or reusable instruments not sterilised in an approved manner-about 11 per cent of all lancing procedures and 91 per cent of all pedicure procedures carried out weekly at the surveyed premises.

\section{DISCUSSION}

There were inadequacies ininfection control among some sectors of the skin penetration industry in NSW, and this did not change significantly after the introduction of the NSW skin penetration guidelines in 1991.

\section{TABLE 4}

SKIN PENETRATION BUSINESSES COMPLYING WITH WASTE-HANDLING GUIDELINES IN 1991 AND 1994 SURVEYS, BYTYPE OF PROCEDURE

\begin{tabular}{|c|c|c|c|c|}
\hline \multirow[b]{2}{*}{ Practice $^{a}$} & \multicolumn{2}{|c|}{$\begin{array}{l}1991 \\
n=78\end{array}$} & \multicolumn{2}{|c|}{$\begin{array}{l}1994 \\
n=72\end{array}$} \\
\hline & $n$ & $\%$ & $n$ & $\%$ \\
\hline \multicolumn{5}{|l|}{ Use of sharps bins } \\
\hline Acupuncture & $7 / 22$ & 32 & $8 / 15$ & 53 \\
\hline Electrolysis & $13 / 28$ & 46 & $16 / 24$ & 67 \\
\hline Lancing & $11 / 19$ & 58 & $16 / 25$ & 64 \\
\hline Pigment implant & $4 / 9$ & 44 & $6 / 8$ & 75 \\
\hline All & 35 & 45 & 46 & $64 \dagger$ \\
\hline \multicolumn{5}{|c|}{$\begin{array}{l}\text { Contaminated waste stored } \\
\text { in approved bags or bins }\end{array}$} \\
\hline Acupuncture & $7 / 22$ & 46 & $6 / 15$ & 27 \\
\hline Electrolysis & $6 / 28$ & 21 & $15 / 25$ & 60 \\
\hline Lancing & $6 / 19$ & 32 & $15 / 25$ & 60 \\
\hline Pigment implant & $2 / 9$ & 22 & $6 / 8$ & $75^{*}$ \\
\hline All & 21 & 27 & 42 & $58 \dagger$ \\
\hline \multicolumn{5}{|c|}{$\begin{array}{l}\text { Contaminated waste removed } \\
\text { by licensed removalist }\end{array}$} \\
\hline Acupuncture & $6 / 22$ & 27 & $6 / 15$ & 40 \\
\hline Electrolysis & $7 / 28$ & 25 & $8 / 24$ & 33 \\
\hline Lancing & $7 / 19$ & 37 & $7 / 25$ & 28 \\
\hline Pigment implant & $2 / 9$ & 22 & $4 / 8$ & 50 \\
\hline All & 22 & 28 & 25 & 35 \\
\hline
\end{tabular}

(a) Some premises undertook more than one procedure. ${ }^{*} P<0.05,+P<0.01$
Although disposable instruments are preferred, reusable instruments continued to be used. Many workers used specialised and expensive lancing instruments, and pedicure procedures were all done with precision skintrimming snips that workers would not consider disposing of after use. Most of these premises were not equipped with adequate sterilisation equipment, and some businesses persisted in reusing skin penetration instruments despite advice from the surveying environmental health officer and the recommendations of the skin penetration guidelines.

The low level of use of approved sterilisation procedures probably reflects a reluctance to invest in expensive technology such as autoclaves. A more cost-effective and appropriate infection control alternative for instruments would be valuable. The predicament of some of the premises surveyed is similar to that of barbers and hairdressers, for whom autoclaving or discarding scissors after each client would be a financial burden.

Although there was a slight improvement in waste disposal practices after the introduction of the guidelines, nearly half of the premises still failed to comply with the Waste Management Authority's recommendations for sharps and contaminated waste storage and disposal.

Although officers provided education for skin penetration operators found to be in breach of the skin penetration guidelines, it was evident that the overall compliance of the skin penetration industry could be improved. Increased emphasis on skin penetration workers' initial training in infection control, the classification, storage and disposal of contaminated waste and the use of disinfectants in accordance with the relevant Australian standard may assist, ${ }^{14}$ as would a heightened promotion of skin penetration workers' continuing trade education. Technical colleges and the industry's professional organisations both have roles to accommodate this training. This need could also be met by local councils through their existing supervisory role. The Department

\section{TABLE 5}

PREMISES FOUND SATISFACTORY INTERMS OF HYGIENE

\begin{tabular}{|lrrrr|}
\hline $\begin{array}{l}\text { Skin penetration } \\
\text { hygiene practices }\end{array}$ & $n^{1991}$ & \multicolumn{3}{c|}{1994} \\
\hline $\begin{array}{l}\text { Presence of hospital- } \\
\text { grade disinfectant }\end{array}$ & 32 & 37 & 41 & $65 \dagger$ \\
$\begin{array}{l}\text { Presence of soap } \\
\text { Presence of hand-wash }\end{array}$ & 14 & 16 & 6 & 10 \\
basin & 13 & 15 & 4 & 6 \\
Total premises inspected & 86 & & 63 & \\
\hline & & & & \\
$T P<0.01$ & & & & \\
\hline
\end{tabular}


of Health is currently reviewing the skin penetration guidelines and will incorporate advice to assist the industry to address these and all relevant infection control issues. Finally, enforcement of the guidelines may be required for repeatedly noncompliant operators.

Tattooists were not included in this survey owing to their small number in the areas surveyed. As was evident from Davis's recent letter on tattoos and hepatitis $\mathrm{C}$, there seems to be a dearth of information on infection control practices of NSW tattooists. ${ }^{15}$ A statewide survey of tattooists would be useful.

\section{ACKNOWLEDGMENTS}

We gratefully acknowledge the assistance of the following Public Health Unit staff: Steve Hatzi, Lorraine Winchester, Danielle Edwards and Trudi Coutts.

\section{REFERENCES}

1. Benenson A. Control of communicable diseases in man. Washington: American Public Health Association, 1990.

2. Reed B, Barrett A, Smith M. The relationship of tattooing to hepatitis B virus exposure [letter] Aust NZ J Med 1985; 15: 769-770.

3. Thompson S, Hernberger F, Wale E, Crofts N. Hepatitis C transmission through tattooing: a case report. Aust $N \mathrm{Z} \mathrm{J}$ Public Health 1996; 20: 317-318.

4. Abildgaard N, Peterslund N. Hepatitis C virus transmitted by tattooing needle [letter]. Lancet 1991; 338: 460.

5. Pavli P, Bayliss J, Dent O, Lunzer M. The prevalence of serological markers for hepatitis B virus infection in Australian Naval personnel. Med J Aust 1989; 151: 71-75.

6. Kent G, Brodum J, Keenlyside R, LaFazia L, Scott H. A large outbreak of acupuncture associated hepatitis B. Am J Epidemiol 1988; 127: 591-598.

7. Backinger C. Skin penetration workers: a critical link in the AIDS education chain? AIDS Educ Prev 1989; 1: 31-38.

8. Turkeltaub S, Habal M. Acute Pseudomonas chondritis as a sequel to ear piercing. Ann Plastic Surg 1990; 24: 279-282.

9. Cumberworth V, Hogarth, T. Hazards of ear piercing procedures which traverse the cartilage: a report of Pseudomonas perichondritis and review of other complications. Br J Clin Pract 1990; 44: 512-513.

10. Skin penetration guidelines. Sydney: NSW Health Department, 1991.

11. Clinical reporting systems, version $2.51 \mathrm{~b}$ [computer program]. Sydney: Clinical Reporting Systems, 1990.

12. SAS System for Personal Computers, Release 6.03. Cary, NC: SAS Institute Inc., 1988.

13. Epi Info Version 5.00. Centers for Disease Control, Atlanta, Georgia, 1990.

14. AS4187. Cleaning disinfecting and sterilizing reusable medical and surgical instruments and equipment and maintenance of associated environments in health care facilities. 2nd edn. Sydney: Australian Standards Association, 1998

15. Davis A R. Tattoo parlours and hepatitis $C$ virus infections. Med J Aust 1995; 163: 556-557.

\section{COMMENT: PROMOTING MENTAL HEALTH IN NSW}

continued from p. 46

Secondly, because mental health is so heavily influenced by social structures and processes at the interpersonal, community, national and international levels, the promotion of positive mental health is, more than any other aspect of health promotion, outside the domains of control and influence of traditional health care services. When promoting mental health, it is necessary but not sufficient to ask: How can we enable people to think fewer negative thoughts (compare this with 'smoke less') or be nicer to their neighbours (compare with 'exercise more'). We must also ask: What sort of society (locally, nationally and internationally) do we want to live in? For instance, do we want

- to destroy the history, culture, environment and selfesteem of some groups to promote the interests of others?

- to create social policies which make it all but impossible for many to feel part of, and participate fully in, society?

- to place all the blame on individuals when a child is battered to death, rather than examine the social conditions that create child abuse?

- to exploit workers in developing countries to satisfy our desire for consumer goods?

- to tolerate, and even sometimes promote, the use of violence as a means of solving international disputes?

These are intensely political questions. To promote the mental health of an individual, we must create societies in which social structures and processes promote positive mental health for everyone, not just a few. Mental health promotion in NSW is a welcome start for the health sector in NSW. We must be careful, however, not to neglect the role played by our own health care and employment practices in promoting and undermining mental health.

\section{REFERENCES}

1. Commonwealth Department of Human Services and Health. Better health outcomes for Australians. National goals, targets and strategies for better health outcomes into the next century. Canberra: Australian Government Publishing Services, 1994.

2. NSW Mental Health Expert Party. NSW mental health goals and targets and strategies for health gain. Sydney: NSW Health Department, 1995.

3. Scanlon K, Williams M, Raphael B. Mental health promotion in NSW: conceptual framework for developing initiatives. Sydney: NSW Health Department, 1997.

4. Ottawa Charter for Health Promotion. World Health Organization and Canadian Public Health Association; International Conference on Health Promotion; 1986 November 17-21; Ottawa. 